\title{
The development of baked kelp snack through examining its physicochemical properties
}

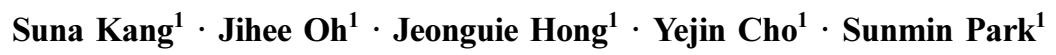 \\ 물리화학적 특성 연구를 통한 구운 다시마 스낵 개발
}

강선아 $^{1} \cdot$ 오지희 ${ }^{1} \cdot$ 홍정의 $^{1} \cdot$ 조예진 ${ }^{1} \cdot$ 박선민 $^{1}$

Received: 28 March 2018 / Accepted: 23 April 2018 / Published Online: 30 June 2018

(C) The Korean Society for Applied Biological Chemistry 2018

\begin{abstract}
The purpose of this study was to develop a kelp (Laminaria japonica) product with optimal sensory and nutritional properties for eating as a snack by investigating its physicochemical properties and conducting sensory evaluation. A preliminary study using tripolypolyphosphate solution found that it was good for removing the fishy smell and for making it soft. We soaked the kelp in $0.3-0.4 \%$ sodium tripolyphosphate buffer and tested with or without baking. In searching for the optimal polyphosphate dilution concentration, soaking in $0.3-0.4 \%$ sodium tripolyphosphate resulted in the best texture and flavor. As kelp separates into thick or thin samples, thick kelp was best when soaked in $0.4 \%$ sodium tripolyphosphate buffer and thin soaked in $0.3 \%$. The kelp snack made from the thick one (over $221 \mathrm{~mm}$ thickness) was better than the thin one. Baking improved the moisture, texture and feel of the kelp snack. Tripolyphosphate treatment affected protein contents and texture softening. The differences by baking and tripolyphosphate treatment were shown with electromicroscopic image. Kelp snacks with added sweet and hot taste were preferred to sour taste. In conclusion, in making kelp snacks, it is advisable to use a thick kelp, $0.3-0.4 \%$ sodium tripolyphosphate, and baking treatment for better texture and feel.
\end{abstract}

Sunmin Park $(\bowtie)$

E-mail: smpark@hoseo.edu

${ }^{1}$ Deptartment of Food \& Nutrition, Institute of Basic Science, Hoseo University, Asan-si, 31499, Republic of Korea

This is an Open Access article distributed under the terms of the Creative Commons Attribution Non-Commercial License (http://creativecommons. org/licenses/by-nc/3.0/) which permits unrestricted non-commercial use, distribution, and reproduction in any medium, provided the original work is properly cited.
This kelp snack has low fishy smell, better taste and soft feel. Further research is needed to support sea food's importance, and usefulness of the kelp snack to help prevent goiter in inland province citizens.

Keywords Baking $\cdot$ Electromicroscopic image $\cdot$ Kelp $\cdot$ Sodium polyphosphate $\cdot$ Texture

\section{서 론}

다시마는 갈조류에 속하는 해양식물로 태평양 연안에서 자생하 며, 국내에서도 쉽게 얻을 수 있는 식품이다. 다시마에는 $\mathrm{K}^{+}$, $\mathrm{Ca}^{2+}, \mathrm{Na}^{+}$등 신진대사와 관련된 알칼리성 무기질이 함유되어 있고(USDA food composition database) 특히 갑상선 호르몬의 성분인 요오드를 다량 함유하고 있어 갑상선 호르몬 생성 및 작용에 도움을 주며[1,2] 당뇨 합병증 개선시키는데 도움을 준 다[3]. 항산화능이 뛰어난 후코이딘을 함유하고 있으며[4,5], 콜 레스테롤 배출을 도와 이상지혈증 예방 및 치료에 도움을 주는 [6,7] 난소화성 식이섬유인 알긴산을 함유하고 있다. 다시마를 발효 추출시킬 때 생기는 Gamma aminobutyric acid는 체지방 감소 및 근력 증가에 도움을 주어 남성 갱년기의 주된 증상인 근감소증(sarcopenia)을 완화시키는데 도움을 준다[8]. 다시마에 는 다양한 기능성물질이 포함되어 있어 다시마에 있는 기능성 물질의 수율을 높이는 연구들도 함께 진행되고 있다[9].

다시마는 주로 중국, 한국, 일본 등 해안을 포함한 동양권에 서 섭취하였고, 이에 대한 연구도 주로 동양에서 수행되어 왔 으며 유럽, 아프리카 등 내륙 지역에서는 해조류 섭취 및 연구 에 대한 관심이 적다. 그러므로 동양에서는 해조류에 포함되어 있는 요오드 부족으로 나타나는 갑상선종(goiter)의 발생이 거의 
없지만, 해조류를 섭취하지 않는 내륙지역의 거주하는 사람들은 갑상선종에 걸릴 확률이 높은데 주된 원인은 요오드 결핍으로 보고되었다[10]. 또한 내륙지역인 유럽과 남아메리카의 일부 지 역에서는 저학년 아동에게 있어서 요오드 결핍은 치명적인 문 제이며 요오드 결핍을 해결하기 위한 방안이 필요하다고 보고 하였다[11]. 요오드는 해조류, 생선, 조개류에서 주로 얻을 수 있으며 요오드를 함유한 토양에서 자란 작물이나 동물, 달걀에 서 얻을 수 있지만, 해조류로 섭취하는 것이 가장 효율적이다 [12].

국내에서 다시마는 주로 국물제조용이나 조미료 재료로 사용 하는 것이 대부분이며, 다시마 분말 첨가 만두피, 고추장, 전통 된장, 국수, 쿠키 등 다시마를 이용한 식품개발 연구 $[13,14,15$, $16,17]$ )가 다양하게 이루어지고 있으나 생산, 양식되는 량에 비 하여 이를 상품화시키는 연구 및 가공기술은 부족한 실정이며 [18] 식량자원 외 사료나 에너지 원료, 의약품 제조 등 다양한 분야에서의 연구 또한 부족한 실정이다[19]. 그리고 고품질의 편리한 식품을 추구하는 소비자의 취향을 만족시키기에 다시마 를 스낵으로 개발하여 판매하거나, 점성이 많은 Gagome kelp 에서 밀가루 대체 파우더를 추출하는 기술 연구[20]를 통해 소 비자 맞춤형 식품을 개발하는 일본에 비해 한국의 해조류 가공 기술의 단계는 아직 미미한 수준이라 할 수 있다. 또한 한국의 대표 해조류 스낵은 밀가루와 김을 이용한 스낵인 김부각을 제 외하면 상용화된 제품은 부족한 실정이므로 다양한 소재의 해 조류로 스낵을 개발하는 것이 필요하겠다.

마른 다시마는 질겨서 씹기 어려운 점이 있고, 표면 조직이 치밀하여 양념이 잘 스며들지 않아 튀기는 부각을 제외하고 스 낵으로 제조하기가 어려운 상황이다. 부각은 수분을 흡수하여
쉽게 눅눅해져 상품성이 떨어지고, 기름기가 많아 쉽게 산패 될 수 있으며 다시마의 건강식품 상품화 이미지와는 맞지 않는다. 그러므로 본 연구에서는 다시마를 튀기지 않은 스낵으로 만들 어, 씹힘성이 좋고, 이물감이 없으며, 비린 향이나 맛을 보완한 맛 좋은 스낵으로 개발하고자 한다. 개발한 다시마 스낵의 물 리화학적 특성을 조사하고자 하였다.

\section{실험 재료 및 방법}

\section{스낵 제조에 적합한 다시마 연화 방법 탐색}

다시마는 씨허브(부산, 한국)에서 구입한 것을 사용하였다. 농도 를 다르게 한 폴리인산나트륨(sodium tripolyphosphate, 이에스 푸드, 경기, 한국)을 이용하여 다시마 연화에 효과가 좋은 농도 를 탐색하였다. 다시마를 흐르는 물에 세척한 후 $2 \times 2 \mathrm{~cm}$ 로 잘 라 농도별로 제조한 폴리인산나트륨 용액에 다시마를 20 분간 담그고 연화시킨 후 식품 건조기에 $70^{\circ} \mathrm{C}, 10$ 시간 동안 건조시 켜 다시마의 연화된 정도를 관찰하였다. 폴리인산나트륨 용액은 $1,0.9,0.8,0.7,0.6,0.5,0.4,0.3,0.2,0.1 \%(\mathrm{v} / \mathrm{v})$ 로 제조하 여 실험에 사용하였고(Fig. 1의 1 step), 고농도로 사용할수록 다시마의 조직이 물러지는 경향이 있으므로 농도를 세분화 하 여 실험을 진행하였다.

\section{폴리인산나트륨 농도에 따른 다시마 두께 측정}

폴리인산나트륨으로 연화시킨 다시마의 두께를 켈리퍼(Calliper, CD-15CPX, Mitutoyo Corp., Kawasaki, Japan)를 사용하여 측 정하였고, 3 회 반복 측정하여 평균값으로 나타내었다.

\author{
1 step Kelp wash (remove salt and foreign substances) \\ $\downarrow$ \\ Kelp selection and cutting $\left(2 \times 2 \mathrm{~cm}^{2}\right)$ \\ $\downarrow$ \\ Grouping (thickness, softening treatment and baking) \\ $\downarrow$ \\ Softening treatment (polyphosphate solution or water)

2 step $\quad \downarrow$ (Thickness and texture of kelp) \\ L1, L3 : Baking at $180^{\circ} \mathrm{C}$ for $8 \mathrm{~min}$ and spray water L2, L4: No baking \\ Dry in drying machine $70^{\circ} \mathrm{C}$ during 10 hours \\ Soaking in the seasoningsolution \\ $\downarrow$ \\ Dry in drying machine $70^{\circ} \mathrm{C}$ during 10 hours \\ To produce kelp snack \\ $\downarrow$ \\ Analysis of physicochemical properties of kelp snack
}

Fig. 1 The manufacturing process of kelp snack with seasoning 


\section{폴리인산나트륨 농도에 따른 다시마 물성 측정}

Texture analyzer (TA-XT Express, Texture Technologies Co. Ltd., Godalming, England)를 사용하여 농도가 다른 폴리인산나 트륨으로 연화시킨 다시마의 경도, 응집성, 검성을 3 회 반복 측 정하여 평균값으로 나타내었다.

다시마 전처리 방법과 조미액의 종류를 달리한 다시마 스낵 제조 연화 농도를 탐색에서 적합한 전처리 시료 및 농도를 선정한 후 다시마 스낵을 제조하였다. 다시마 스낵에 적합한 다시마 전 처리 방법은 Fig. 1에 step 1에서 정한 $0.4 \%$ 폴리인산나트륨용 액에 침지하는 것이고, 전처리한 다시마를 굽거나 말려서 양념 한 스낵 제조 방법은 Fig. 1에 주었다. 자세히 설명하면 다시마 를 흐르는 물에 세척하여 염분을 제거한 후, 다시마의 두께가 $221 \mathrm{~mm}$ 미만인 것은 얇은 것으로 분류하였고, $221 \mathrm{~mm}$ 이상인 것은 두꺼운 것으로 분류하였다. 다시마를 $2 \times 2 \mathrm{~cm}$ 로 자르고, 폴 리인산나트륨 용액 혹은 물에 침지시켜 연화시켰다(얇은 다시 마: $0.3 \%$ 폴리인산나트륨 용액 혹은 물에 10 분 침지, 두꺼운 다시마: $0.4 \%$ 폴리인산나트륨 용액 혹은 물에 15 분 침지). step 2 에서는 연화시킨 다시마를 오븐에 $180{ }^{\circ} \mathrm{C}$ 에서 8 분간 굽거나 굽 는 처리를 하지 않고, 조미액에 침지시켜 단맛, 신맛, 매운맛을 낸 후 건조기(L'equip 식품건조기, LD-918BT, 서울, 한국)에서 $70{ }^{\circ} \mathrm{C}, 10$ 시간 동안 건조시켜 다시마 스낵을 제조하였다. 다시 마의 두께와 폴리인산나트륨 용액을 이용한 연화 처리 및 굽는 처리에 따른 제조 군 분류는 Table 3에 나타내었다.

다시마의 영양과 맛을 증가시키기 위해 단맛, 신맛, 매운 맛 조미액을 제조하여 다시마를 침지시킨 후 스낵을 제조하였고 조 미액의 분류는 Table 4에 나타내었다. 단맛 조미액은 파인애플 갈은 것 $80 \mathrm{~mL}(\mathrm{~S} \& W, \mathrm{San}$ Francisco, USA), 설탕 $80 \mathrm{~g}$ (씨제 이제일제당(주), 인천, 한국), 생강농축액 $40 \mathrm{~mL}$ (영농조합법인 완주봉상생강조합, 전북, 한국), 소금 $3 \mathrm{~g}$ (대상주식회사, 서울, 한 국)을 물 $200 \mathrm{~mL}$ 에 혼합하여 제조하였고, 신맛 조미액은 설탕 $80 \mathrm{~g}$, 골드키위 갈은 것 $60 \mathrm{~mL}$ (순천연합조합공동사업법인, 전 남, 한국), 생강즙 $40 \mathrm{~mL}$, 레몬즙 $60 \mathrm{~mL}$ (Eurofood S.R.L, Salerno SA, 이탈리아), 식초 $60 \mathrm{~mL}$, 소금 $2 \mathrm{~g}$ 을 물 $200 \mathrm{~mL}$ 에 혼합하여 제조하였으며 마지막으로 매운 맛은 설탕 $70 \mathrm{~g}$ 에 생 강즙 $40 \mathrm{~mL}$, 파프리카 시즈닝 $60 \mathrm{~g}$ (에프앤에스식품, 경기도, 한 국), 쓰리라차 $60 \mathrm{~mL}$ (HuyFong Foods, Inc, Los Angeles, $\mathrm{CA}, \mathrm{USA})$, 소금 $3 \mathrm{~g}$ 을 물 $200 \mathrm{~mL}$ 에 혼합하여 제조하였다.

\section{다시마 스낵의 수분함량 및 일반 성분 측정}

수분함량 및 일반 성분은 두꺼운 다시마로 측정하였고, 다시마 의 수분함량은 상압 건조 가열법으로 측정하였다. 수기를 항량 한 후, 다시마 조각 $0.5 \mathrm{~g}$ 을 넣고 $105 \pm 1{ }^{\circ} \mathrm{C}$ 건조기에 넣어 5 시 간동안 건조시킨 후, 데시케이터 안에서 30 분간 식힌 뒤 항량 될 때까지 무게를 측정하고 항량된 무게를 3 회 반복 측정하였 다. 수분함량은 아래와 같이 계산하였다.

$$
\begin{aligned}
& \text { 수분함량 }(\%)=(\mathrm{W} 2-\mathrm{W} 3) /(\mathrm{W} 2-\mathrm{W} 1) \times 100 \\
& \mathrm{~W} 1: \text { 수기의 항량 }(\mathrm{g}) \\
& \mathrm{W} 2: \text { 시료와 수기의 무게 }(\mathrm{g}) \\
& \mathrm{W} 3: \text { 항량된 시료와 수기의 무게 }(\mathrm{g})
\end{aligned}
$$

조회분 함량은 도가니에 다시마 $5 \mathrm{~g}$ 을 넣고 태우고 남은 회분 으로 측정하였다. 조회분을 측정할 도가니를 항량한 후 다시마 를 담아 도가니 집게를 사용하여 회화로(FD1530M, Industrial Benchtop Muffle Furnace, ThermoFisher, Texas, USA)에 넣고 $550-600{ }^{\circ} \mathrm{C}$ 에서 $4-5$ 시간 가열한 후 회백색의 회분을 얻는다. 온 도가 내려가면 식혀서 데시케이터에 넣어 30 분간 방치한 후 조 회분을 칭량하는 방법으로 3 회 측정하여 평균값으로 나타내었 다. 조회분 함량식은 아래와 같다.

$$
\text { 회분 함량 }(\%)=(\mathrm{W} 1-\mathrm{W} 0) / \mathrm{S} \times 100
$$

$\mathrm{W} 0$ : 항량된 도가니의 무게 $(\mathrm{g})$

$\mathrm{W} 1$ : 회화 후 도가니와 회분의 무게 $(\mathrm{g})$

$\mathrm{S}$ : 시료채취량 $(\mathrm{g})$

조지방 함량은 soxhlet 추출법을 사용하여 측정하였다. 다시마 $5 \mathrm{~g}$ 을 원통 여과지에 넣고 탈지면으로 덮은 후 soxhlet extractor 에 장착하였다. 무수에테르를 약 $1 / 2$ 용량을 넣어 장치하고 8 시간동안 조지방을 추출하였다. 추출이 끝난 후 에테르는 완전 증발 시킨 후 $100{ }^{\circ} \mathrm{C}$ 건조기에서 1시간 방치시킨 후 데시케이 터로 옮겨 조지방량을 측정하였고, 3 회 측정하여 평균값으로 나 타내었다. 조지방 측정 식은 아래와 같다.

\section{조지방 함량 $(\%)=(\mathrm{W} 1-\mathrm{W} 0) / \mathrm{S} \times 100$}

$$
\begin{aligned}
& \mathrm{W} 0 \text { : 그릇의 무게 }(\mathrm{g}) \\
& \mathrm{W} 1 \text { : 조지방 추출 후 건조시킨 그릇의 무게 }(\mathrm{g}) \\
& \mathrm{S} \text { : 시료 채취량 }(\mathrm{g})
\end{aligned}
$$

다시마 $5 \mathrm{~g}$ 을 킬달 플라스크에 넣고 분해촉진제(황산구리: 황산 칼륨 $=1: 4$ 용액)를 넣은 후 황산 $5 \mathrm{~mL}$ 를 넣고 과산화수소를 조 금씩 넣어 반응시킨다. 플라스크를 가열하고 분해액이 청색으로 변할 때까지 가열시킨 후, 분해액을 냉각시키고 증류 장치에 연 결하였다. 증류 장치의 흡수 플라스크에 $0.05 \mathrm{~N}$ 황산용액을 브 런스위크 시약을 2-3방울 떨어뜨리고 냉각기의 끝부분을 액면 에 담근 후 $30 \%$ 수산화나트륨 용액을 넣고 증류액은 녹색이 될 때까지 수산화나트륨 용액으로 적정하여 질소 함량을 측정 하였다. 공시험은 뷰렛시약을 이용하여 측정하였고, 다시마의 조 단백함량은 3 회 측정하여 평균값으로 나타내었으며, 측정 식은 아래와 같다.

\section{조단백함량 $(\%)=\mathrm{N}(\%) \times$ 질소계수}

$$
\text { 질소계수: } 6.25
$$

\section{다시마 스낵의 물성 측정}

Texture Analyzer (TA-XT Express, Texture Technologies Co., Ltd.)를 사용하여 두꺼운 다시마로 제조한 스낵의 경도, 응집성, 검성을 측정하였고 얇은 다시마에서는 부서짐이 심해 두꺼운 다 시마로만 측정하였다. Test mode는 texture profile analysis (TPA)로, 측정 조건에서 speed 값은 pre test는 $2 \mathrm{~mm} / \mathrm{s}$, test 1 $\mathrm{mm} / \mathrm{s}$, post test에는 $1 \mathrm{~mm} / \mathrm{s}$ 값을 주었고, trigger force는 $5 \mathrm{~g}$, distance는 $25 \mathrm{~mm}$ 로 값을 주었고, Plunger는 cylinder type TA$11 \mathrm{ss}$ 를 사용하였다. 시료는 3 회 반복 측정하여 평균값으로 구하 였다. 


\section{다시마 스낵의 색도와 표면 및 측면 구조 측정}

색도는 색차계(JC-801S, Color Techno System, Tokyo, Japan) 를 이용하여 측정하였다. 색도 결과는 명도 $\mathrm{L}^{*}$ (lightness), 적색 도 $\mathrm{a}^{*}$ (redness), 황색도 $\mathrm{b}^{*}$ (yellowness)로 나타내었고, 실험은 4회 반복 측정하여 평균값으로 나타내었다. 다시마의 측면과 표 면을 전자현미경(scanning electron microscope, FEI, Hillsboro, $\mathrm{OR}$, Oregon, USA)으로 10,000 배 촬영하여 비교하였다.

\section{다시마 스낵 관능 평가}

제조한 다시마 스낵은 호서대학교 대학생에서 공지하고 자원자 15 명을 선정하여 이들을 대상으로 관능 평가 동의서를 받고 조 미액 첨가 전, 후의 다시마에 대한 관능 평가를 진행하였다. 5 점 척도로 평가를 진행하였고, 조미 처리를 하지 않은 다시마 스낵은 전체적기호도, 냄새(fishy smell), 바삭함(crispiness), 이 에 붙는 정도(stickiness), 맛(taste), 전체적 기호도(overall acceptance)로 5 가지를 평가하였고, 조미 처리를 한 다시마는 의 평가 항목은 향 기호도(flavor preference), 맛(taste)을 추가하여 7 가지 항목을 평가하였다. 각 항목별로 5점에서 1점까지 점수 를 주도록 교육하였고, 매번 평가를 진행하기 전 물로 입안을 헹구고 난 후 평가를 진행하도록 하였다(5점: 매우 좋다, 4점: 좋다, 3점: 보통이다, 2점: 싫다, 1점: 매우 싫다).

\section{통계분석}

실험의 모든 통계 처리는 SPSS (Statistical Package for Social Science, version 18.0)를 이용하여 평균 \pm 표준편차로 표시하였 다. 연화 농도 탐색 실험에서 폴리인산나트륨의 농도에 따른 통 계적 유의성은 one-way ANOVA로 Tukey test를 사용하여 $p<0.05$ 의 수준에서 검정하였다. 다시마 스낵 제작에서 굽는 처 리와 연화 용액에 따른 통계적 유의성은 two-way ANOVA를 수행하고 통계적으로 차이가 있는 것은 Tukey test를 사용하여 군별 차이를 $p<0.05$ 의 수준에서 검정하였다.

\section{결과 및 고찰}

\section{스낵 제조에 적합한 다시마 연화 방법 탐색}

다시마 연화에 적합한 폴리인산나트륨 용액 농도를 탐색하기 위 해 농도가 다른 폴리인산나트륨 용액으로 연화시킨 다시마의 두 께를 측정하였다(Table 1). 다시마의 두께는 1-0.8, 0.7-0.4, 0.3$0.1 \%$ 순으로 높은 값을 나타내는 경향을 보였고 $(p<0.05)$, 맛은 $0.5 \%$ 이상의 농도로 폴리인산나트륨을 처리한 것은 떫고 쓴맛 이 강하고 식감이 물렀고, $0.4 \%$ 이하에서는 맛과 식감이 양호 하였다. Song 등[21]은 다시마 연화에서 $0.3 \%$ 이상의 폴리인산 나트륨에서 탁월한 연화 효과를 보였고 초산, 중탄산나트륨보다 폴리인산나트륨 용액으로 연화시킨 것이 가장 효과적이었다고 보고하였다. 실험 결과, 폴리인산나트륨 용액이 다시마의 질감 을 향상시키는 역할[22]을 한 것으로 보이며 알긴산이 폴리인 산나트륨 용액에 용해되면서 다시마의 연화에 영향을 미친 것 으로 된다. 다시마를 연화시킬 때 폴리인산나트륨 용액을 사용 하고, 그 농도는 $0.2-0.3 \%$ 가 적합한 것으로 보인다.
Table 1 The thickness and appearance of kelp treated with sodium tripolyphosphate

\begin{tabular}{cccc}
\hline \hline $\begin{array}{c}\text { Concentration } \\
(\%)\end{array}$ & Thickness & Appearance & Taste \\
\hline 1 & $221.7 \pm 0.1^{\mathrm{e}}$ & Too liquefaction & Sticky and bitterness \\
0.9 & $221.7 \pm 0.1^{\mathrm{e}}$ & Liquefaction & Bitterness \\
0.8 & $221.7 \pm 0.1^{\mathrm{de}}$ & Liquefaction & Bitterness \\
0.7 & $221.9 \pm 0.1^{\mathrm{cd}}$ & Somewhat liquefaction & Bitterness \\
0.6 & $221.8 \pm 0.0^{\mathrm{d}}$ & Softening & Bitterness \\
0.5 & $222.2 \pm 0.1^{\mathrm{c}}$ & Softening & Bitterness \\
0.4 & $222.1 \pm 0.2^{\mathrm{c}}$ & Normal spread & Normal taste \\
0.3 & $222.5 \pm 0.2^{\mathrm{b}}$ & Normal spread & Normal taste \\
0.2 & $222.7 \pm 0.2^{\mathrm{ab}}$ & Normal spread & Normal taste \\
0.1 & $222.9 \pm 0.1^{\mathrm{a}}$ & Normal spread & Normal taste \\
\hline
\end{tabular}

${ }^{\mathrm{a} e \mathrm{e}}$ Different alphabets indicate significant differences among the groups by Tukey's test at $p<0.05$

Table 2 The texture properties of kelp treated with sodium tripolyphosphate

\begin{tabular}{cccc}
\hline \hline $\begin{array}{c}\text { Concentration } \\
(\%)\end{array}$ & Hardness & Cohesiveness & Gumminess \\
\hline 1.0 & $0.02 \pm 0.01^{\mathrm{d}}$ & $0.99 \pm 0.09^{\mathrm{a}}$ & $0.02 \pm 0.00^{\mathrm{e}}$ \\
0.9 & $0.05 \pm 0.00^{\mathrm{d}}$ & $0.86 \pm 0.07^{\mathrm{ab}}$ & $0.04 \pm 0.01^{\mathrm{e}}$ \\
0.8 & $0.06 \pm 0.01^{\mathrm{d}}$ & $0.99 \pm 0.11^{\mathrm{a}}$ & $0.05 \pm 0.00^{\mathrm{e}}$ \\
0.7 & $0.10 \pm 0.00^{\mathrm{d}}$ & $0.90 \pm 0.03^{\mathrm{a}}$ & $0.09 \pm 0.00^{\mathrm{d}}$ \\
0.6 & $0.10 \pm 0.00^{\mathrm{d}}$ & $0.76 \pm 0.01^{\mathrm{b}}$ & $0.08 \pm 0.00^{\mathrm{d}}$ \\
0.5 & $0.22 \pm 0.08^{\mathrm{d}}$ & $0.53 \pm 0.09^{\mathrm{c}}$ & $0.11 \pm 0.01^{\mathrm{d}}$ \\
0.4 & $0.47 \pm 0.04^{\mathrm{d}}$ & $0.83 \pm 0.13^{\mathrm{ab}}$ & $0.39 \pm 0.06^{\mathrm{c}}$ \\
0.3 & $1.22 \pm 0.32^{\mathrm{c}}$ & $0.70 \pm 0.1^{\mathrm{b}}$ & $0.84 \pm 0.17^{\mathrm{b}}$ \\
0.2 & $2.57 \pm 0.24^{\mathrm{b}}$ & $0.66 \pm 0.13^{\mathrm{bc}}$ & $1.65 \pm 0.23^{\mathrm{a}}$ \\
0.1 & $4.22 \pm 0.97^{\mathrm{a}}$ & $0.50 \pm 0.12^{\mathrm{c}}$ & $2.12 \pm 0.67^{\mathrm{a}}$ \\
\hline
\end{tabular}

$\overline{{ }^{a}-\mathrm{e}}$ Different alphabets in the same column indicate significant differences among the groups by Tukey's test at $p<0.05$

\section{폴리인산나트륨 용액의 농도에 따른 다시마 물성 측정}

폴리인산나트륨 용액으로 연화시킨 다시마의 물성 측정 결과는 Table 2에 나타내었다. 경도는 두께와 유사한 결과를 나타내었 는데 농도가 1 에서 $0.1 \%$ 로 갈수록 순차적으로 높아지는 경향 을 보였다. 응집성은 폴리인산나트륨 용액에서는 $1,0.8 \%$ 에서 높은 값을, $0.5,0.1 \%$ 에서는 낮은 값을 나타내었다. 검성은 두 처리군 모두 경도 결과와 유사하였다. 실험결과는 폴리인산나트 륨 용액을 처리하였을 때 농도가 높아짐에 따라 경도 값이 낮 아진다고 보고한 Jeong 등[23]의 연구와 동일하였다. 폴리인산 나트륨 용액은 다시마뿐만 아니라 어육가공품, 돼지고기 가공에 도 사용되며, 폴리인산나트륨 용액 농도 변화에 따른 결과의 변 화는 본 실험과 유사하였다 $(0.15 \%$ tripolyphosphate-hardness: 2,687, cohesiveness: $45.8 ; 0.45 \%$ tripolyphosphate-hardness: 2,175, cohesiveness: 63.5)[24]. Kim과 Joo[25] 저작, 연하가 용이한 식품 연구에서 최적화된 음식의 물성 기준이 경도는 2.4 $(\mathrm{N})$, 부착성은 $-1.87(\mathrm{~g} \times \mathrm{s})$ 이 저작 연하 단계의 물성 기준에 적 합한 수준이라고 보고하였는데[25], 다시마 연화 농도에서 0.2- 
Table 3 The groups of kelp treated with sodium tripolyphosphate and baking process

\begin{tabular}{ccccc}
\hline \hline \multicolumn{2}{c}{ Group } & Water & $\begin{array}{c}\text { Sodium } \\
\text { tripolyphosphate }\end{array}$ & Baking \\
\hline \multirow{4}{*}{ Thin } & LN1 & & $0.3 \%$ soaking & $180^{\circ} \mathrm{C}, 8 \mathrm{~min}$ \\
kelp & LN2 & & $0.3 \%$ soaking & - \\
& LN3 & soaking & & $180^{\circ} \mathrm{C}, 8 \mathrm{~min}$ \\
& LN4 & soaking & & - \\
\hline \multirow{4}{*}{ Thick } & LK1 & & $0.4 \%$ soaking & $180^{\circ} \mathrm{C}, 8 \mathrm{~min}$ \\
kelp & LK2 & & $0.4 \%$ soaking & - \\
& LK3 & soaking & & $180^{\circ} \mathrm{C}, 8 \mathrm{~min}$ \\
& LK4 & soaking & & - \\
\hline
\end{tabular}

Table 4 Seasoning ingredients of kelp snack

\begin{tabular}{lccc}
\hline \hline & Sweet sauce & Sour sauce & Spicy sauce \\
\hline Pineapple juice & $160 \mathrm{~mL}$ & & \\
kiwi juice & & $60 \mathrm{~mL}$ & \\
Lemon juice & & $60 \mathrm{~mL}$ & \\
Vinegar & & $60 \mathrm{~mL}$ & \\
Sriracha sauce & & & $80 \mathrm{~mL}$ \\
Paprika seasoning & & & $80 \mathrm{~g}$ \\
Ginger juice & $40 \mathrm{~mL}$ & $40 \mathrm{~mL}$ & $40 \mathrm{~mL}$ \\
Salt & $3 \mathrm{~g}$ & $2 \mathrm{~g}$ & $3 \mathrm{~g}$ \\
Sugar & $100 \mathrm{~g}$ & $80 \mathrm{~g}$ & $100 \mathrm{~g}$ \\
Water & $200 \mathrm{~mL}$ & $200 \mathrm{~mL}$ & $200 \mathrm{~mL}$ \\
\hline \multicolumn{1}{c}{ Total } & 503 & 503 & 503 \\
\hline
\end{tabular}

$0.3 \%$ 의 폴리인산나트륨 용액으로 연화시킨 다시마가 김 등의 물성 결과와 유사한 것으로 보아 섭취하기 용이한 물성 값을 가지는 것으로 보인다.

\section{다시마 스낵의 수분함량 및 일반 성분 함량}

다시마 스낵의 수분함량은 구운 것에서 더 높은 값을 나타내었 는데 이는 굽는 처리 후 조미액에 침지시킬 때 굽는 처리를 한 다시마가 굽는 처리를 하지 않은 다시마보다 조미액을 더 많이 흡수하여 위와 같은 결과가 나온 것으로 사료된다. 조회분과 조 지방 함량에서는 굽는 처리와 관련 없이 폴리인산나트륨 용액 에 침지시킨 것에서 유의적으로 높은 값을 나타내었고, 조단백 질 함량은 물에 침지시킨 것에서 더 높게 나타나는 경향을 보 였으나 유의적인 차이는 없었다(Table 5). Suraiya 등[26]의 연 구에 따르면 강낭콩 발효에 쓰이는 Monascus purpureus 로 다 시마를 발효시키면 다시마의 단백질과 항산화물질의 함량이 증 가한다고 보고하였고, 발효시킨 다시마 추출물이 고지혈증이나 당뇨환자에게 권장한다고 보고하였는데 폴리인산나트륨 용액이 Monascus purpureus와 유사한 작용을 하여 다시마의 조회분 함 량의 변화에 영향을 미친 것으로 보이며, 조직을 구성하는 단 백질을 분해하여 다시마가 부드러워지면서 단백질의 함량이 줄 어든 것으로 사료된다. 또한 다시마는 상, 중, 하층부에 따라 조 단백질과 조회분 함량이 다르므로[27], 중층부의 다시마를 사용 하여 스낵을 제조하면 조단백질과 조회분 함량이 적절하게 포 함되어있는 스낵을 제조할 수 있을 것으로 보인다.
Table 5 The proximate compositions of kelp snack

\begin{tabular}{ccccc}
\hline \hline & $\begin{array}{c}\text { Moisture } \\
\text { contents }(\%)\end{array}$ & Crud ash (\%) & $\begin{array}{c}\text { Crud protein } \\
(\%)\end{array}$ & Crud fat (\%) \\
\hline LK1 & $10.2 \pm 0.0^{\mathrm{b}}$ & $15.1 \pm 0.1^{\mathrm{a} *}$ & $7.42 \pm 0.04^{\mathrm{b}}$ & $0.57 \pm 0.01^{\mathrm{a} *}$ \\
LK2 & $9.8 \pm 0.0^{\mathrm{c}}$ & $15.4 \pm 0.2^{\mathrm{a}}$ & $6.06 \pm 0.05^{\mathrm{c}}$ & $0.57 \pm 0.01^{\mathrm{a}}$ \\
LK3 & $10.6 \pm 0.0^{\mathrm{a} \dagger}$ & $13.5 \pm 0.4^{\mathrm{b}}$ & $7.29 \pm 0.04^{\mathrm{b}}$ & $0.53 \pm 0.01^{\mathrm{b}}$ \\
LK4 & $10.1 \pm 0.0^{\mathrm{b}}$ & $13.2 \pm 0.2^{\mathrm{b}}$ & $8.32 \pm 0.03^{\mathrm{a}}$ & $0.4 \pm 0.01^{\mathrm{c}}$ \\
\hline
\end{tabular}

LK indicated kelp snack made of thick kelp. In softening treatment, 1, 2 indicated using sodium polyphosphate and 3, 4 indicated water. In baking treatment, 1, 3 indicated baking, 2, 4 no baking

${ }^{a-c}$ Different alphabets in the same row indicate significant differences among the groups by Tukey's test at $p<0.05$

*Significant difference by the sodium tripolyphosphate and water treatment in two-way ANOVA at $p<0.05$

'Significant difference between baking and no baking treatment by Tukey's test in two-way ANOVA at $p<0.05$

Table 6 The texture properties of kelp snack

\begin{tabular}{cccc}
\hline \hline Group & Hardness & Cohesiveness & Gumminess \\
\hline LK1 & $0.34 \pm 0.13^{\mathrm{d}}$ & $0.92 \pm 0.06$ & $0.3 \pm 0.1^{\mathrm{c}}$ \\
LK2 & $2.1 \pm 0.05^{\mathrm{b}}$ & $0.9 \pm 0.01$ & $1.91 \pm 0.04^{\mathrm{a}}$ \\
LK3 & $1.43 \pm 0.17^{\mathrm{c}}$ & $0.86 \pm 0.06$ & $1.25 \pm 0.24^{\mathrm{b}}$ \\
LK4 & $2.51 \pm 0.28^{\mathrm{a} \dagger}$ & $0.87 \pm 0.04$ & $2.16 \pm 0.17^{\mathrm{a} \dagger}$
\end{tabular}

LK indicated kelp snack made of thick kelp. In softening treatment, 1, 2 indicated using sodium tripolyphosphate and 3, 4 indicated water. In baking treatment, 1, 3 indicated baking, 2, 4 no baking

${ }^{a-c}$ Different alphabets in the same row indicate significant differences among the groups by Tukey's test at $p<0.05$

'Significant difference between baking and no baking treatment by Tukey's test in two-way ANOVA at $p<0.05$

Table 7 The chromaticity of kelp snack

\begin{tabular}{cccc}
\hline \hline Group & $\mathrm{L}^{*}$ lightness & $\mathrm{a}^{*}$ redness & $\mathrm{b}^{*}$ yellowness \\
\hline LN1 & $18.0 \pm 0.3^{\mathrm{b}}$ & $1.49 \pm 0.1^{\mathrm{a}}$ & $3.98 \pm 0.59^{\mathrm{ab}}$ \\
LN2 & $21.0 \pm 0.2^{\mathrm{a}}$ & $1.30 \pm 0.13^{\mathrm{ab}}$ & $4.69 \pm 0.19^{\mathrm{a}}$ \\
LN3 & $20.8 \pm 0.3^{\mathrm{a}}$ & $1.43 \pm 0.04^{\mathrm{ab}}$ & $4.79 \pm 0.21^{\mathrm{a}}$ \\
LN4 & $21.7 \pm 0.1^{\mathrm{ac}}$ & $1.09 \pm 0.03^{\mathrm{b}}$ & $3.03 \pm 0.17^{\mathrm{b}}$ \\
LK1 & $20.3 \pm 0.2^{\mathrm{b}}$ & $3.19 \pm 0.02^{\mathrm{b}}$ & $6.65 \pm 0.03^{\mathrm{b}}$ \\
LK2 & $15.5 \pm 0.5^{\mathrm{c}}$ & $1.08 \pm 0.35^{\mathrm{c}}$ & $2.24 \pm 0.58^{\mathrm{c}}$ \\
LK3 & $23.5 \pm 0.9^{\mathrm{ac}}$ & $4.26 \pm 0.14^{\mathrm{ac}}$ & $9.38 \pm 0.38^{\mathrm{ac}}$ \\
LK4 & $16.3 \pm 0.3^{\mathrm{c}}$ & $1.24 \pm 0.22^{\mathrm{c}}$ & $2.16 \pm 0.09^{\mathrm{c}}$ \\
\hline
\end{tabular}

LN indicated kelp snack made of thick kelp and LK indicated thick kelp. In softening treatment, 1, 2 indicated using sodium tripolyphosphate and 3, 4 indicated water. In baking treatment, 1, 3 indicated baking, 2, 4 no baking

${ }^{\mathrm{a} c}$ Different alphabets in the same row indicate significant differences among the groups by Tukey's test at $p<0.05$

'Significantly different between baking and no baking by Tukey's test in two-way ANOVA at $p<0.05$

\section{다시마 스낵의 물성 측정}

두꺼운 다시마 스낵의 물성 측정 결과는 Table 6에 나타내었다. 경도와 검성 값은 물에 침지시키고 굽지 않은 것이 높게 나타 났고 $(p<0.05)$, 응집성은 폴리인산나트륨 용액에 침지시킨 것이 높게 나타났으나 유의적인 차이는 없었다. 경도와 검성은 양의 


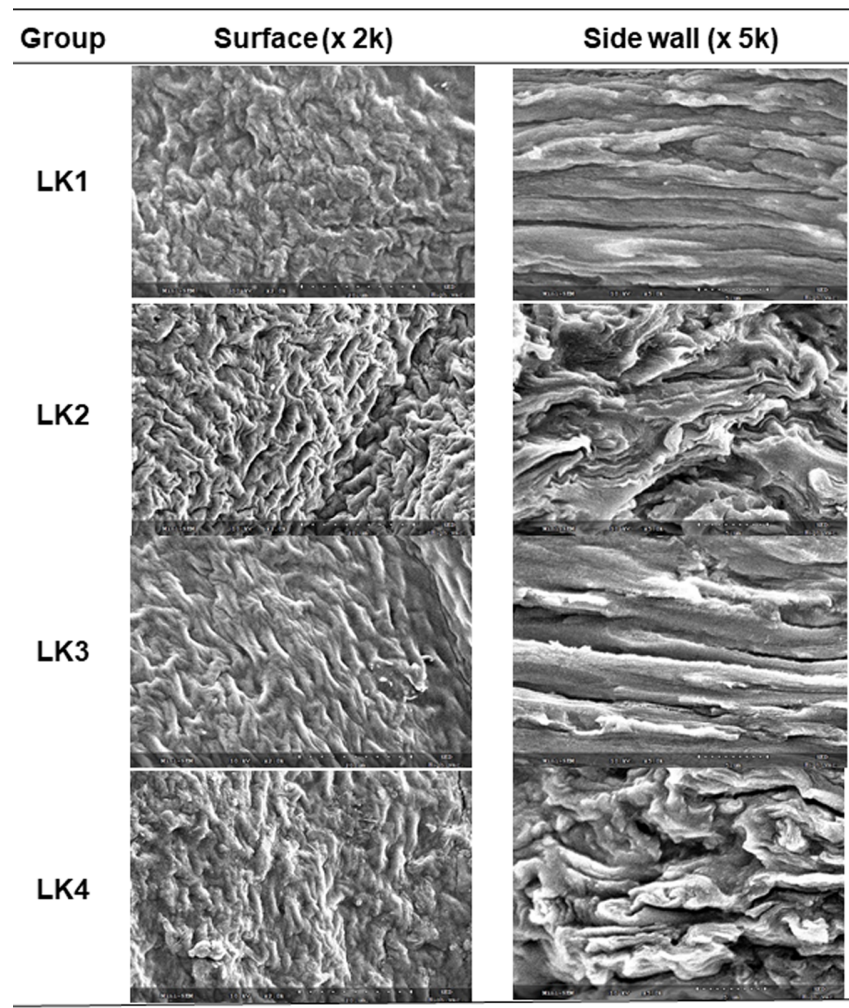

Fig. 2 The electron micrographs of surface and side wall of kelp treated with sodium tripolyphosphate and baking. LK indicated kelp snack made of thick kelp. In softening treatment, 1, 2 indicated using sodium tripolyphosphate and 3,4 indicated water. In baking treatment, 1, 3 indicated baking, 2,4 no baking

상관관계를 가지는 것으로 보이며, 폴리인산나트륨 용액으로 침 지시킨 것은 다시마 조직을 구성하는 알긴산과 단백질이 분해 되면서 경도 값이 낮게 나온 것으로 사료된다. 폴리인산나트륨 용액 처리와 열처리는 다시마의 연화에 영향을 미치는데 폴리 인산나트륨 용액의 경우 $0.2 \%$ 에서, 열처리의 경우 $100^{\circ} \mathrm{C}$ 에서 30 분간 가열 조건이 다시마 연화에 탁월하므로[21] 폴리인산나 트륨 용액을 처리하고 굽는 처리를 한 다시마의 물성 값이 적 합한 값을 나타낸 것으로 사료된다. 전통적 방법으로 제조한 김 부각의 저장성에 대해 연구한 박 등의 실험에서는 김부각을 0 일에서 20 일간 보관하였을 때 5.9-7.84의 경도 값을 나타내었는 데[28], 본 실험에서 제조한 다시마 스낵이 0.3-2.51 값을 나타 내는 것을 보면 김부각보다 더 부드러운 것을 알 수 있다.

\section{다시마 스낵의 색도 및 외형 측정}

두께가 다른 다시마의 색도 측정 결과는 Table 7에 나타내었다. 두꺼운 다시마는 굽는 처리를 한 다시마의 값이 전반적으로 높 은 값을 나타내었고 침지시키는 용매에 따른 차이는 없었다. 다 시마 분말의 경우 저장기간이 증가함에 따라 황색도 값이 증가 하는데[29], 양지에서 건조시킨 다시마의 황색도는 증가하였으 나, 음지에서 건조시킨 다시마의 황색도는 그 값의 변화가 크 지 않은 것으로 보아(kelp dried in sunny spot: 11.5, kelp dried in shady spot: $-9.72[30]$, 음지에서 건조한 다시마로 스

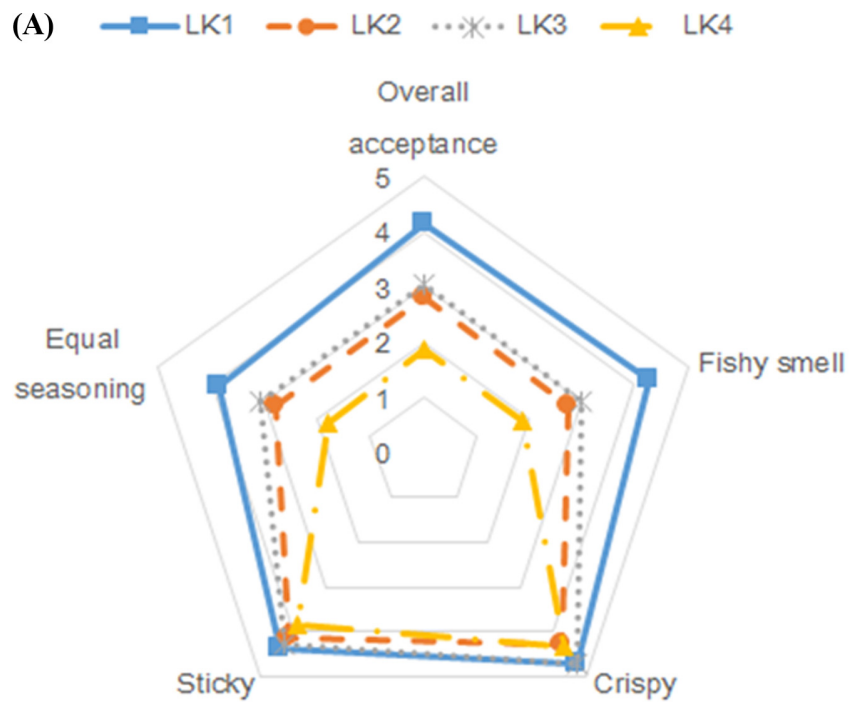

(B)

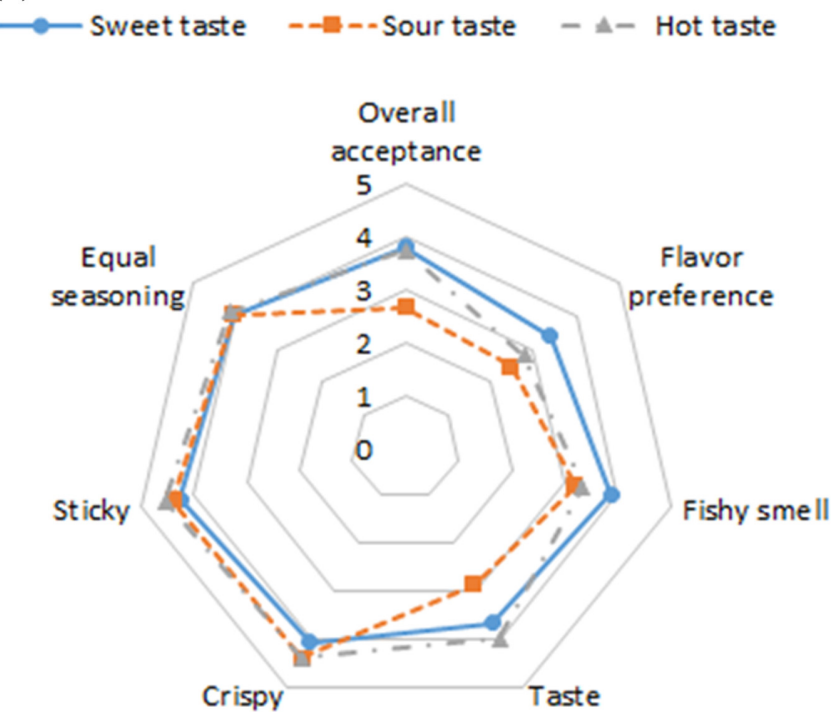

Fig. 3 Sensory evaluation of kelp snack. Thick kelp treated with sodium tripolyphosphate and baking treatment. The kelp snack with different seasonings. LK indicated kelp snack made of thick kelp. In softening treatment, 1, 2 indicated using sodium tripolyphosphate and 3, 4 indicated water. In baking treatment, 1, 3 indicated baking, 2, 4 no baking

낵을 제조할 경우 고품질의 다시마 스낵을 제조할 수 있을 것 으로 보인다. 얇은 다시마에서는 그 값이 일관된 결과를 보이 지 않았는데, 그 두께가 얇아, 빛이 반사되지 못하고 투과되어 위와 같은 값이 나온 것으로 사료된다.

전자현미경 촬영 결과, 폴리인산나트륨 용액 처리와 굽는 처 리에 의한 다시마의 외형 변화가 나타났다(Fig. 2). 폴리인산나 트륨 용액을 처리하지 않은 것은 조직이 길게 이어지는 모습을 보이는 반면, 폴리인산나트륨 용액을 처리한 것은 다시마 조직 의 경계가 짧아지고 무르는 경향을 보였다. 굽는 처리를 한 다 시마는 굽지 않은 것에 비하여 표면이 부드러웠다. 이 결과는 물성 측정에서 경도 값과 관련이 있는데, LK1과 3에서 굽는 처 리로 인해 조직이 부드러워지면서 낮은 경도 값을 가지게 되고, 
$\mathrm{LK} 2$ 와 4에서는 다시마 조직이 수축되면서 경도 값이 높아진 것 을 확인 할 수 있다.

\section{다시마 스녁 관능 평가}

조미 처리를 하지 않은 다시마 스낵의 관능 평가 결과는 Fig. $4 \mathrm{~A}$ 에, 조미 처리를 한 다시마 스낵은 Fig. $3 \mathrm{~B}$ 에 나타내었다. 조 미하지 않은 다시마 스낵에서는 굽는 처리를 한 다시마 스낵이 높은 점수를 받았고, 물보다는 폴리인산나트륨 용액을 처리한 다시마에서 높은 점수를 받았다. 결과가 가장 좋았던 폴리인산 나트륨 용액 처리와 굽는 처리를 한 다시마로 조미 다시마 스 낵을 제조하여 관능 평가를 진행한 결과, 단맛과 매운맛은 전 반적으로 높은 점수를 받았고, 신맛은 조미의 균일함과 이에 붙 는 정도, 바삭한 정도에서는 높은 점수를 받았지만 전체적 기 호도와 향, 맛에서 낮은 점수를 받았다. 다시마를 가공하여 다 시마 칩을 제조한 $\mathrm{Kim}$ 의 연구[31]에서는 찜, 탈수, 살짝 튀긴 후 오래 끓이는 braising, 열처리 등의 가공 처리를 하였는데, braising 처리와 냉동 혹은 가열 건조 처리한 샘플이 비린 향이 없고 씹힘성이 좋았다고 보고하였다. 굽는 처리를 한 다시마의 결과가 가장 좋았던 것과 유사한 것으로 보아 폴리인산나트륨 용액에 침지시키고 굽는 처리를 한 후, 단맛과 매운 맛 조미를 하여 제조한 다시마 스낵이 가장 맛이 좋고 상품성이 있는 제 품으로 보인다.

\section{초 록}

미역이나 다시마와 같은 해조류는 생물의 상태로 유통될 수 없 는 어려움이 있어 건조, 염장, 당장 등의 가공 처리가 필요하다. 본 실험에서는 다시마를 건조 및 전처리를 하여 해조류에 거부 감을 가지고 있는 내륙지역에서도 쉽게 접근할 수 있는 스낵으 로 제조하고, 맛과 씹힘성이 좋으며 비린 맛이 없어 누구나 좋 아하는 스낵을 개발하고, 개발한 스낵의 물리화학적 특성을 연 구하였다.

다시마 연화에 탁월한 폴리인산나트륨 용액 농도 탐색 실험 에서는 $0.2-0.3 \%$ 농도의 폴리인산나트륨 용액에 침지시키는 것 이 다시마 연화나 맛에서 좋았고 부드러운 질감을 나타내었다. 폴리인산나트륨 용액 침지 및 굽는 처리를 달리한 다시마 스낵 제조에서는 두께가 $221 \mathrm{~mm}$ 미만인 것은 얇은 것으로, $221 \mathrm{~mm}$ 이상인 것은 두꺼운 것으로 분류하여 실험을 진행하였는데, 두 꺼운 다시마 스낵에서 모든 실험 결과에서 일관된 결과를 보이 는 반면 얇은 다시마의 경우 일관된 결과를 보이지 않아 두꺼 운 다시마로 스낵을 제조하는 것이 바람직해 보였다. 다시마 스 낵은 굽는 처리를 한 것이 수분함량과 조회분 함량에서 유의적 으로 높은 값을 나타내었으며, 폴리인산나트륨 용액에 침지시킨 것이 낮은 경도 값을 나타내는 것으로 보아 폴리인산나트륨 용 액에 침지로 인해 다시마가 부드러워지는 것을 확인할 수 있었 다. 전자현미경 촬영 결과 폴리인산나트륨 용액에 침지시키고 굽는 처리를 한 다시마 스낵이 조직이 부드러워지는 것과 좋은 질감을 가지는 것을 확인할 수 있었다.

다시마로 스낵을 제조할 때는 단백질과 회분 함량이 적절하 게 포함된 중층부 다시마의 두꺼운 부분을 사용하는 것이 좋으 며, 음지에서 건조시킨 다시마를 사용하는 것이 저장성이 높은
다시마 스낵을 제조하는데 바람직할 것으로 보인다. 가공 처리 의 경우 폴리인산나트륨 용액에 침지 및 굽는 처리를 하여 단 맛이나 매운맛의 조미를 가하여 다시마 스낵을 제조할 경우 이 물감이 없고 씹힘성이 좋으며 비린 맛이 없는 상품성이 높은 다시마 스낵을 제조할 수 있을 것으로 보인다. 해조류 섭취의 중요성에 대한 연구들이 뒷받침된다면 다시마 스낵이 남미에 수 출되면 갑상선종에 대한 예방이 가능하고 수출 증대로 국가적 이익을 창출 할 수 있을 것으로 기대된다.

Keywords 굽는 처리 · 다시마 · 물성 · 전자현미경 이미지 · 폴 리인산나트륨

감사의 글 이 연구는 2016년도 정부(미래창조과학부)의 재원으로 한국연구 재단-전통문화융합연구사업의 지원을 받아 수행된 연구 결과입니다 (No. NRF-2016M3C1B5907152). 전자현미경으로 다시마의 표면과 측면을 촬영해 준 호서대학교 신소재공학과 김빛찬님께 감사드립니다.

\section{References}

1. Miyai K, Tokushige T, Kondo M (2008) Suppression of thyroid function during ingestion of seaweed "Kombu" (Laminaria japonoca) in normal Japanese adults. Endocrin J 55: 1103-1108

2. Jurkoviæ N, Kolb N, Coliæ I (1995) Nutritive value of marine algae Laminaria japonica and Undaria pinnatifida. Mol Nutr Food Res 39: 6366

3. Cho YJ, Bang MA (2004) Hypo-glycemic and anti-oxidative effects of dietary sea-tangle extracts supplementation of streptozotocin-induced diabetic rats. Korean Nutr Soc 37: 5-14

4. Xue C, Chen L, Li Z, Cai Y, Lin H, Fang Y (2004) Antioxidative activities of low molecular fucoidans from kelp Laminaria japonica. In Developments in Food Sci 42: 139-145

5. Kang YM, Lee BJ, Kim JI, Nam BH, Cha JY, Kim YM, Je JY (2012) Antioxidant effects of fermented sea tangle (Laminaria japonica) by Lactobacillus brevis BJ20 in individuals with high level of $\gamma$-GT: a randomized, double-blind, and placebo-controlled clinical study. Food Chem Toxicol 50: 1166-1169

6. Kim YY, Lee KW, Kim GB, Cho TJ (2000) Studies on physicochemical and biological properties of depolymerized alginate from sea tangle, Laminaria japonicus by thermal decomposition. J Korean Fish Soc 33: 388-392

7. Lee HS, Choi MS, Lee YK, Park SH, Kim YJ (1996) A study on the development of high-fiber supplements for diabetic patients - effect of seaweed supplementation on the lipid and glucose metabolism in streptozotocin-induced diabetic rats. Kor J Soc Food Sci Nutr 29: 296306

8. Choi WC, Reid Strom NS, Ryu JK, Kim YS, Jo YH, Jeon BH (2016) Effects of $\gamma$-aminobutyric acid-enriched fermented sea tangle (Laminaria japonica) on brain derived neurotrophic factor-related muscle growth and lopolysis in middle aged women. Algae 31: 175-187

9. Kim WJ, Lee JK, Chang YS (1994) Development of combined method for extraction of sea tangle. Korean J Food Sci Technol 236: 51-56

10. George K. Hans PD, Jurgen B, Gerhard H (1997) Randomized, double blind, placebo-controlled trial of low dose iodide in endemic goiter. J Clin Endocrinol Metab 82: 4049-4053

11. Michael BZ, Kevin C, Maksim B, John B, Fabian R, Lindita G (2006) Iodine supplementation improves cognition in iodine-deficient schoolchildren in Albania: a randomized, controlled, double-blind study. Am J Clin Nutr 83: 108-114

12. Rohner F, Zimmermann M, Jooste P, Pandav C, Caldwell K, Raghavan R, Raiten DJ (2014) Biomarkers of Nutrition for Development-Iodine 
Review-4. J Nutr 144: 1322-1342

13. Bae TJ, Choi OS (2001) Changes of free amino acid compositions and sensory properties in Kochujang added sea tangle powder during fermentation. Korean J Food Nutr 14: 245-254

14. Cui CB, Lee EY, Lee DS, Ham SS (2002) Antimutagenic and anticancer effects of ethanol extract from Korean traditional Doenjang added sea tangle. J Korean Soc Food Sci Nutr 31: 322-328

15. Bang SJ, Shin IS, Kim SM (2006) Optimum process condition of noodles with sea tangle single cell detritus (SCD). Korean J Food Sci Technol 38: 68-74

16. Park ID (2015) Quality characteristics of dumpling shell with sea tangle powder. Korean J Soc Food Preserv 22: 190-196

17. Cho HS, Park BH, Kim KH, Kim HA (2006) Antioxidative effect and quality characteristics of cookies made with sea tangle powder. Korean J. Food Culture 21: 541-549

18. Lim JH. Jung ST, Park YK, Kang SK, Kim SJ, Kim DH, Park J, Kim CH (2004) Development of value-added products and functional food materials using seaweeds. Dissertation, Mokpo University

19. Jo BW, Choi BB, Jo H, Choi SK, Son JS, Yoon DS, Ryu BY, Jung YS, Son JY, Choi JS, Choi YS, Choi ES, Lim NK, Park OR (2007) Process development for the production of functional materials using sea mustard and sea tangle. Chosun University

20. Seguchi M, Iseki K, Tabara A (2017) Study of a gluten-free bread made from Gagome kelp (Kjellmaniella crassifolia Miyabe). J Biochem Biotech 1: 25-30

21. Song JC, Shin WC, Park HJ (2004) Softening studies of raw sea tangle texture for improvement of it's processing compatibility. Korean J Food
Nutr 17: 186-192

22. Patashnik M, Keyes M (1973) Animal food from raw whole fish. US Patent 3,730,728, 1, 7 May, 1973

23. Jeong IH, Lee KS, Lee KH (1994) The effect of additives to the texture of kelp blade. Bull. Kor Fish Soc 27: 149-154

24. Moon YH (2002) Effects of adding polyphosphate on the water holding capacity and palatability of boiled pork loin. Kor J Food Sci Ani Resour 22: $130-136$

25. Kim SJ, Joo NM (2014) Development of easily chewable and swallowable Korean barbecue beef for the aged. Kor J Food Nutr 27: $1175-1181$

26. Suraiya S, Lee JM, Cho HJ, Jang WJ, Kim DG, Kim YO, Kong IS (2018) Monascus spp. fermented brown seaweeds extracts enhance biofunctional activities. Food Biosci 21: 90-99

27. Shin TS, Xue Z, Do YW, Jeong DS, Woo HC, Kim NG (2011) Chemical properties of sea tangle (Saccharina, japonica) cultured in the different depths of sea water. Clean Technol 17: 395-405

28. Park JI, Chung GH, Kim BS, Hur JH (1994) A study on the preparation of boogags by traditional methods and improvement of reservation. J Kor Soc Food Sci Nutr 23: 986-933

29. Jung HA, Kim AN, Ahn EM, Park SH, Kim MJ, Yoo YJ, Lee YR (2011) Study development of salad dressing with added sea tangle (Laminaria japonica). Korean J Food Nutr 24: 520-527

30. Jung HK, Ahn HK (2000) The algae production supplies for a life. Sci Fair 46

31. Kim CW (2017) Kelp chip manufacturing method. US Patent Application Publication 2017, 0112172, 27 Apr 2017 